\title{
Strategies to Improve Halal Tourism in Indonesia During The Pandemic Covid-19
}

\author{
Anita Musfiroh $^{\left.1^{*}\right)}$, Mugiyati ${ }^{2)}$, Aldi Khusmufa Nur Iman $^{3)}$ \\ ${ }^{1,2,3}$ Pascasarjana, Universitas Islam Negeri Sunan Ampel Surabaya \\ * Email correspondence: anitamusfiroh99@gmail.com
}

\begin{abstract}
The Covid 19 has had an impact on various sectors of human life. One of them is the tourism sector. The tourism industry which is predicted to be the second largest source of foreign exchange contributions for Indonesia has experienced a drastic decline. Likewise, the halal tourism sector has also been severely affected by the Covid 19 pandemic. This is because the key to developing the halal tourism sector is Muslim tourists or visitors who come. To revive the tourism sector, it requires a number of strategies prepared by the government to improve the economy in the halal tourism sector. The purpose of writing this article is to find out how the impact of Covid 19 on the halal tourism sector and how the strategy to revive the halal tourism sector during the Covid 19 pandemic. The method used in this study is a qualitative method with data collection techniques used is literature study. The results of the study state that the strategy to restore the halal tourism sector from the Covid 19 pandemic consists of 3 stages and recommendations for implementing health protocols. The existence of this strategy and also the health protocol is expected by the enthusiastic community to return to enliven the tourism sector, including halal tourism.
\end{abstract}

Keywords: halal tourism, tourism, covid 19

Saran sitasi: Musfiroh, A., Mugiyati., \& Iman, A. K. (2021). Strategies to Improve Halal Tourism in Indonesia During The Pandemic Covid-19. Jurnal Ilmiah Ekonomi Islam, 7(02), 1048-1052. doi:http://dx.doi.org/10.29040/jiei.v7i2.2533

DOI: http://dx.doi.org/10.29040/jiei.v7i2.2533

\section{INTRODUCTION}

Halal tourism is a rapidly increasing industry area in both Muslim and non-Muslim nations. Non-Muslim nations such as Australia, Taiwan, Korea, Japan, and European nations, in particular, cater to this tourism market (halal travel). Nearly 1.7 billion Muslims live in countries where they can travel with their families and friends. Muslims used to go overseas for Hajj and Umrah. However, they now devote a significant amount of time to tourism in addition to Hajj and Umrah (Chookaew et al., 2015).

As part of Indonesia's efforts to increase halal tourism (halal tourism). The Indonesian government is attempting to promote the presence of Sharia hotels through the Minister of Tourism and Creative Economy's Regulation, which establishes standards for the establishment of sharia hotels. In 2013, there were 37 halal-certified sharia hotels and 150 hotels on the verge of becoming sharia-compliant. There are also 2,916 eateries, of which 303 have been certified halal and 1,800 are in the process of becoming certified (Satriana \& Faridah, 2018). Furthermore, the Ministry of Tourism will learn from other countries that have implemented the concept of halal tourism, such as Malaysia, which was already known as a halal tourism destination, as well as socializing with tourism organizations in Indonesia, such as the Indonesian Hotel and Restaurant Association (Association of Indonesian Hotels and Restaurants. PHRI) and the Association of Indonesian Hotels and Restaurants (Association of Indonesian Hotels and Restaurants) (ASITA) (Jaelani, 2017).

Based on previous research, the Indonesian Ministry of Tourism has developed tourist destinations or destinations to increase the number of tourists from within and outside the country in order to develop the halal tourism industry in Indonesia through three aspects. The first aspect is that the Indonesian Ministry of Tourism has developed tourist destinations or destinations to increase the number of tourists from within and outside the country. The second point is about marketing development in order 
to attract more Muslim visitors or tourists. The government has taken use of technical advancements in promoting the advancement of Indonesian tourism in the modern era. The growth of human resources, society, and industry is the third aspect. This factor has to do with commercial competitiveness and the ability of institutions or organizations to manage and provide tourism services (Hermawan, 2019).

The number of international tourists that visited Indonesia in 2019 totaled 16.11 million, an increase of 1.88 percent over the same time in 2018 , when the figure was 15.81 million (Budiyanti, 2020) Various aspects of human existence have been affected significantly since the Covid-19 epidemic broke out. The tourist industry is one of the most hit. The tourist industry, which is expected to be Indonesia's second greatest source of foreign exchange contribution, has seen a significant downturn. According to data published by the Central Statistics Agency, international visitors from China visited Indonesia in 2019, accounting for 2.07 million people, or 12.8 percent of all international visitors. As a result of the COVID-19 outbreak, the number of visitors visiting Indonesia continues to fall. The COVID-19 epidemic has also impacted tourism-related businesses such as restaurants, hotels, and retailers (Nasution et al., 2020).

Similarly, the Covid 19 epidemic has had a significant impact on the halal tourist industry. A total of 1,434,041 foreign Muslim visitors entered Indonesia, accounting for $18.24 \%$ of the overall number of 8,044,462 tourists. The majority of Muslim visitors to Indonesia came from Malaysia, Singapore, Saudi Arabia, India, and Australia, according to the data (Pratiwi, n.d.). However, as a result of the implementation of social and physical distance, the number of Muslim visitors from outside declined dramatically in 2020, along with the drop in foreign flights. Domestic Muslim tourists also witnessed a downturn.

To resurrect the tourist sector, a lot of policies are required to enhance the economy in the tourist industry, particularly halal tourism, which is unable to withstand the negative effects of Covid-19. The tourist sector's revival is critical because, in 2019, the tourist sector's foreign exchange reached IDR 280 trillion, the tourist industry contributed 5.5 percent to national GDP, and the tourist sector's workforce reached 13 million people (Kontan, 2020). Indonesia is also regarded as the Qibla of Halal Tourism in the World.
Indonesia won 12 prize categories at the 2016 World Halal Tourism Awards, making it the most awarded country in the world (Jaelani, 2017).

Covid-19's declaration as a worldwide pandemic in March 2020 has a huge influence on the tourist industry, notably Muslim-friendly or halal tourism. Both tourist business actors and part-time employees or day laborers who rely on daily revenue to satisfy their basic requirements are directly affected by this epidemic. The decrease in visitor arrivals has a direct effect on income in this industry. To preserve the Muslim-friendly tourist sector from a major economic disaster, strategic and targeted actions to cope with the effects of Covid-19 are urgently needed.

Therefore, the purpose of this research is to answer how the impact of Covid 19 on halal tourism and strategies to improve or restore the halal tourism sector during the Covid-19 pandemic.

\section{RESEARCH METHOD}

This study uses a qualitative approach. The data collection technique used is a literature study, by collecting library documentation from articles, journals, or books, as well as publication data from other parties who are sources for researching the problems in this article related to strategies for increasing halal tourism during the Covid 19 Pandemic.

The data analysis technique consists of three steps, namely data reduction, data presentation, and drawing conclusions. Data reduction is the process of selecting, focusing on simplifying, abstracting, and transforming raw data. Data reduction includes: summarizing data, coding, tracing themes, and creating clusters. Data presentation is an activity when a collection of information is compiled, thus giving the possibility of drawing conclusions and taking action.

\section{RESULTS AND DISCUSSIONS}

\section{The Impact of Covid-19 on the Halal Tourism Sector}

The influence of Covid-19 on the tourist sector cannot be isolated from halal tourism as an integrated program with the National Tourism Development. Halal tourism has the same influence on the tourist industry as does tourism in general. One of the industries worst hit by the Covid-19 epidemic is tourism. Not only that, but the Covid-19 epidemic has had a substantial impact on the tourism industry, with 
management of tourist destinations, airlines, hotels, travel agencies, and restaurants all temporarily closing their doors. This situation has arisen as a result of a decrease in the number of local and international visitor visits (KNEKS, 2020).

The hospitality business, especially Halal Tourism, is affected by the decrease in tourist visitation. The percentage of rooms occupied dropped from $25 \%$ to $50 \%$. Room rental rates dropped ten percent to twenty-five percent, while hotel turnover dropped 25 percent to fifty percent. According to the PHRI, 1,642 hotels in 31 provinces were shuttered as of April 13, 2020. With 501 hotel closures, West Java Province is the province with the most hotel closures. In addition, the province of Bali has 281 hotels. DKI Jakarta has 100 hotels while East Java has 144 hotels.

According to Luhut Binsar Panjaitan, Coordinating Minister for Maritime Affairs and Investment, the tourist sector's losses owing to the corona virus epidemic were US \$ 500 million each month, or about 7 trillion rupiah. According to a research undertaken by the Republic of Indonesia's Ministry of Tourist and Creative Economy, the tourism sector would only recover in 2022, and it may even worsen in 2023. (KNEKS, 2020).

The direct impact of this pandemic is felt by parttime workers or day laborers who rely on daily income to meet their daily needs. In addition, salary cuts, giving unpaid leave to layoffs often occur due to the cessation of the economy. Based on PHRI data, around 8.1 million employees were laid off due to the corona outbreak with a total of 9 million employees. This means that $90 \%$ of hotel and restaurant employees have been laid off due to sluggish business during this pandemic.

The Virtual Scientific Discussion organized by the Tourism Communication Research Group on April 29, 2020 presented some data related to the impact of Covid 19 on the Indonesian tourism sector, including:

- Hotel occupancy in Bali 0-8\%

- 180 destinations and 232 tourist villages are closed until the second week of April 2020

- 7,804 employees were laid off based on an online survey of 50 operators from 16 provinces

- Sales of the retail sector, particularly shopping centers, fell by $95 \%$.

Based on a study conducted by the Ministry of Tourism and Creative Economy of the Republic of Indonesia, the tourism industry will only recover in 2022 , it could even be worse in 2023. Halal tourism as an integrated program with the National Tourism Development certainly cannot be separated from the impact of Covid-19 in the tourism sector. The impact experienced by halal tourism is the same as the impact on tourism in general.

\section{Strategies to Increase Halal Tourism During the COVID-19 Pandemic}

According to the Ministry of Tourism and Creative Economy, the implementation of the strategy to increase halal tourism is divided into three stages, including (KNEKS, 2020): Stage 1 (February - May 2020), referred to as the Emergency Response stage, during which the government allocates funds to the Covid-19 disaster mitigation program. 19, determine the impact of the Covid-19 pandemic on tourism, support social movements in the tourism sector, implement Go Digital programs (e-learning, e-library, and e-sharing), and develop tourism crisis management mechanisms and strategies that are integrated with Covid-19 crisis management and the activation of the Tourism Crisis Center (TCC).

Furthermore, in Phase 2 (June - December 2020), referred to as the Recovery Phase, destinations, industry, institutions, and marketing are being prepared. First and foremost, the government focuses on providing assistance to tourism sites in order to improve amenities, tourist attractions, and IMTIstandard accessibility. Second, encourage investmentfriendly policies and the development of the halal tourist industry. Third, the tourist industry should be prioritized in national, regional, and international recovery efforts, as well as in national development aid.

Furthermore, according to Riyanto Sofyan, Chairman of the Indonesian Halal Tourist Association (PPHI), the halal tourism business was able to withstand the pandemic crisis. There are numerous things that must be done, such as the overhaul or breakdown of the business model, because the most essential item in tourism is cash flow management, which may be accomplished by restructuring expenses in the tourist industry. Even if it is losing money, a tourist business can be considered to be functioning if it has cash flow; but, if the cash flow is halted, the tourist firm may be considered to be dead or bankrupt. Furthermore, a partnership system for tourist players must be implemented so that tourism may breathe easier with restricted financial flow (KNEKS, n.d.).

During Phase 3 (January - December 2021), referred to as the Normalization Phase, the focus is on 
Activating Promotions in a variety of ways, including 1) adjusting marketing to actual conditions through DOT (Destination, Origin, Time) marketing strategies, BAS (Branding, Advertising, Selling) promotion strategies, and POSE media strategy (Paid Media, Owned Media, Social Media, Endorser). 2) Increase marketing reach both at home and abroad by publishing, branding, and participating in Muslimfriendly tourist events. 3) Organizing events for the Muslim tourism sector and assisting tourism sites in their rapid growth. 4) Improving human resource development (talents) and putting sustainable Muslim-friendly tourism on the work agenda.

The implementation of strategy in the new normal period differs slightly from the prior strategy. One of the most important criteria in the execution of this new normalcy protocol is regional preparation and cooperation from industrial participants and the creative economy. According to the Minister of Tourism and Creative Economy, the Cleanliness, Health, and Safety (CHS) initiative would engage all players in the tourism sector and the creative economy (parekraf), as well as allied ministries or organizations, as a new normal arrangement in tourist areas. This is a tourist and creative economy plan to ensure that the neighborhood remains productive and secure after Covid 19.

In addition, the Association of Indonesian Travel Companies (ASITA) has also prepared several recommendations for the Covid-19 protocol in the new normal period for the tourism sector. This Covid19 protocol is important as a guideline for tourism actors and tourists to prevent the transmission of the corona virus. Some of the protocol recommendations include:

a. Body temperature checks for employees and visitors to tourist attractions

b. Setting the working time so that it is not too long

c. Abolished the third shift period. Even if the third shift must be applied, then the task is handed over to workers who are under 40 years old.

d. Providing additional supplements, such as vitamin $\mathrm{c}$ to employees

e. Mandatory use of masks for both employees and visitors

f. Clean areas every four hours, including toilets and prayer rooms.

\section{Provide hand washing facilities}

This protocol focuses more on health, hygiene, and reducing physical contact for a safe travel experience (KNEKS, n.d.). With the strategy in the new normal era and also the health protocol, it is hoped that the community will be enthusiastic to return to enliven the tourism sector, including halal tourism.

\section{CONCLUSION}

Based on the results and discussions described previously, it can be concluded that: The Covid-19 pandemic has had a significant impact on the tourism sector, including halal tourism. The tourism sub-sector such as airlines, hotels, travel agencies, and restaurants are also affected by this pandemic. This condition is due to the decrease in the number of tourist visits, both domestic and foreign.

The strategy to restore the halal tourism sector during the COVID-19 pandemic is through three stages:

a. Phase 1 (February - May 2020) which is the Emergency Response Phase: Prioritizing public health, tourism activities are stopped.

b. Phase 2 (June - December 2020) namely Recovery Phase: Preparing Destinations, Industry, Institutions, and Marketing.

c. Phase 3 (January - December 2021) namely Normalization Phase: Activate promotion.

\section{ACKNOWLEDGMENTS}

We would like to offer our appreciation to many parties for their important assistance, direction, and recommendations, as well as advise, in completing this research. We would like to thank Allah SWT for His kindness and favor, which has enabled us to accomplish this research. Thanks go out to Dr. Mugiyati, S.Ag., MEI, who assisted in the production of this journal paper and taught us a lot of new things.

\section{REFERENCE}

Budiyanti, E. (2020). Dampak Virus Corona Terhadap Sektor Perdagangan Dan. 2015.

Chookaew, S., chanin, O., Charatarawat, J., Sriprasert, P., \& Nimpaya, S. (2015). Increasing Halal Tourism Potential at Andaman Gulf in Thailand for Muslim Country. Journal of Economics, Business and Management, 3(7), 739-741. https://doi.org/10.7763/joebm.2015.v3.277

Hermawan, E. (2019). Strategi Kementerian Pariwisata Indonesia Dalam Meningkatkan Branding Wisata Halal. Jurnal Ilmu Manajemen Dan Akuntansi, 7(2), 87-95. 
Jaelani, A. (2017). Halal Tourism Industry in Indonesia: Potential and Prospects. SSRN Electronic Journal, 76237. https://doi.org/10.2139/ssrn.2899864

KNEKS. (n.d.). Komite Nasional Ekonomi dan Keuangan Syariah.

KNEKS. (2020). Laporan Perkembangan Pariwisata Ramah Muslim Daerah.

Kontan. (2020). Sepanjang 2019, devisa sektor pariwisata mencapai $R p 280$ triliun.
Nasution, D. A. D., Erlina, E., \& Muda, I. (2020). Dampak Pandemi COVID-19 terhadap Perekonomian Indonesia. Jurnal Benefita, 5(2), 212. https://doi.org/10.22216/jbe.v5i2.5313

Pratiwi, A. E. (n.d.). ANALISIS PASAR WISATA SYARIAH DI KOTA YOGYAKARTA. Junah Media Wisata, 14 Nomor 1, 1-21.

Satriana, E. D., \& Faridah, H. D. (2018). Halal Tourism: Development, Chance and Challenge. Journal of Halal Product and Research, 1(2), 32. https://doi.org/10.20473/jhpr.vol.1-issue.2.32-43 